\title{
Research on International Commercial Law Course Teaching Method Based on Cross-discipline Universal Analysis
}

\author{
Xiaopeng Zhang \\ Chengdu Neusoft University, Chengdu, 611844, China
}

Keywords: inter-disciplinarity; universal analysis; international trade; Commercial law, curriculum teaching; methodological exploration

\begin{abstract}
Economic globalization has enabled rapid development of international commercial activities, which objectively requires more versatile applied talents who understand both international economic management and international commercial law rules in our country's higher education. The teaching of relevant content of international commercial law rules is mainly reflected in the international commercial law curriculum. Therefore, the international commercial law curriculum has received more and more attention and has become a legal compulsory course for students majoring in economic management. However, as a legal course established by the non-law major, its teaching purpose, teaching task, and the knowledge background of the teaching subject are fundamentally different from those of the law major. Therefore, its teaching methods cannot copy the teaching methods of the international commercial law of law major.
\end{abstract}

\section{Introduction}

Influenced by the traditional Chinese teaching philosophy, at present, the teaching of international commercial law in our colleges and universities is still a single mode of classroom instruction, which is the mode of "passing knowledge-accepting knowledge". Many teachers have adopted the traditional teaching methods consistently adopted in Chinese law education in the teaching process, namely, the law, legal interpretation and case analysis. At the time of the lecture, the legal provisions are first discussed, followed by the commentary on the law and the analysis of the final case. The purpose is to enable students to use the law to solve practical problems. However, after the author found out through practical teaching, this kind of teaching method is not ideal. There are many students rote memorizing cases and they do not know why this deal with legal issues. Its teaching content only pays attention to book theory knowledge, but ignores the content of its practice. This teaching method can only be a "filled duck" full house irrigation teaching method.

International business law courses mainly reflect the basic content of international commercial treaties, international commercial practices, and domestic commercial laws of various countries. The contents of the international commercial law curriculum are quite numerous and complicated. For 
example, on the same issue, there are different legal provisions for civil law systems and common law systems, international treaties, and international conventions. Even within the same legal system, there are differences between German law and French law, English law, and American law. Due to the lack of systematic legal knowledge and lack of knowledge of foreign legal systems and social environment, the students have a heavy task of teaching and teaching. Therefore, proper teaching methods must be adopted to achieve better teaching results.

The traditional lecture-style education in Chinese universities also has its advantages. For example, the imparted professional knowledge is organized and systematic, making it easy for students to take notes and master. However, the teaching method has its own unique defects, which are mainly manifested in: it is not conducive to the cultivation of students' creative thinking, because the students are in a passive state of listening in class all the time, unable to mobilize the enthusiasm of the students, creative thinking problems; not conducive to training Students use legal and legal skills to independently analyze and solve problems. Because students accept mainly books legal knowledge and research results processed by teachers' intelligence in the classroom, they rarely have the opportunity to discuss actual cases in the classroom. In particular, students of foreign trade and economics do not have a legal basis like those of law majors, and the chapters of international commercial law cover a large amount, and their theoretical and application capabilities are relatively high. In this case, if the teacher is still teaching in accordance with the "spoon-fed" method of the past, when using the method of teachers speaking and students listening during the course, students can easily detach from the course, lose interest in learning, and blindly remember.

\section{The Proposed Methodology}

\subsection{The Concept of International Commercial Law}

International commercial law is the sum of legal norms and practices that regulate various relationships between international commercial transactions and commercial organizations. What it adjusts is the equal commercial transactions between companies, companies, and other commercial organizations. The legal sources are only international treaties and international commercial practices. For example, Schmitov, a British scholar, believes that international commercial law is a law that regulates international business organizations to conduct international commercial transactions within the scope of private law. It differs from international economic law and is not subordinate to private international law. The origins of international commercial law are mainly commercial practices and international legislation. Some domestic scholars also hold similar views, arguing that international commercial law is the sum of legal norms regulating international commercial transactions and various commercial organization relations. Its legal sources are related international conventions and international trade practices and do not include domestic laws. They include companies in scope. Law, Contract Law, International Sale of Goods Law, Product Liability Law, Agency Law, Negotiable Instruments Law, International Air, Sea and Air Transport Law, Marine Insurance Law, and International Commercial Arbitration Law.

Eclectic. Scholars who hold this view believe that international commercial law is a general term for adjusting various legal norms and legal practices of international commercial transactions and international commercial organizations. Its origins include international treaties, international practices, and domestic laws, but they vary in scope. Some scholars believe that international commercial law mainly includes agency law, partnership food law, company law, foreign investment enterprise law, contract law, sale and purchase law, product liability law, bill law, and international commercial arbitration law. Some scholars believe that the contents include the Commercial Organization Law, Agency Law, Contract Law, International Cargo Sale Law, International Cargo 
Transportation Law, International Cargo Insurance Law, Negotiable Instruments Law, International Commercial Conduct Law, International Commercial and Maritime Litigation and Arbitration. Some scholars believe that the contents include the international law of the sale of goods, the international intellectual property and international technology transfer law, the international trade in services law, and the legal regulation of international commercial transactions. At present, this kind of trade-off has gradually become the mainstream theory in the international business and law community and is widely recognized by all.

The curriculum development of institutions of higher learning has the following characteristics: First, it must be emphasized that the construction of the curriculum obeys the needs of society. According to the needs of society, the development of science and technology, and the constant changes in academic research, new requirements have been put forward for curriculum development. Second, we must scientifically use the Marxist world outlook, methodology, and the basic principles of education to guide the construction of the curriculum. Third, curriculum construction is a systematic project. It not only discusses and reforms some individual teaching factors or teaching links, but also comprehensively analyzes the interrelationships between various teaching factors. From the teaching system as a whole, consider the construction of teaching factors.

\subsection{The Constraints of International Commercial Law Teaching Methods}

Teaching methods are the measures adopted by teachers to achieve teaching goals and accomplish teaching tasks, and teaching objectives and teaching tasks must be completed within a certain teaching time. Teaching methods should be adjusted according to teaching objectives, teaching content, teaching hours, and the knowledge background of the subject. There is no difference between the advantages and disadvantages of teaching methods. Only the right ones are the best teaching methods. Therefore, in order to choose the appropriate teaching method, we must analyze the background factors of the choice of teaching method of ICC curriculum.

Any teaching activity must be centered around the teaching objectives. The setting of course teaching objectives should be adapted to the professional training objectives. The professional teaching objectives of economic management are to cultivate knowledge, ability and knowledge in economics, management, law, etc., to analyze and solve related problems in the economic management process, and to adapt to the needs of economic management, and to have complex and applied talents with certain innovation capabilities. . Under this professional training goal, the goal of the ICC curriculum is to enable students to master the basic principles and main content of international business law. In international business activities, they can be based on international commercial law and can flexibly apply international commercial law knowledge to solve international commercial disputes. The goal of the training of law majors is to cultivate professional legal personnel, and there is a fundamental difference between the teaching objectives of international economic law and the management of specialized fields. Therefore, the teaching of international commercial law in the economics and management specialties cannot be copied from the teaching methods of the international commercial law courses of law schools and should be flexibly adjusted according to their training objectives.

As an independent legal department, the determination of the international commercial law system depends on the development of the commercial relations across national borders. Therefore, the system of international commercial law has always been in the course of continuous development and changes with the development of transnational commercial activities. As a subdiscipline of international law, international commercial law should include specific content, and domestic scholars have no consensus. From the perspective of the current development of international commercial law, it is generally believed that the main components of the national commercial law 
system include the international commercial principal law, the international commercial conduct law, and the international commercial rights relief law. Each component in the form of expression is an organic component of international treaties, international conventions, and domestic laws. It can be seen that the development, complexity, and diversity of international commercial law systems. The management of professional international commercial law courses is usually 32 hours or 48 hours. Therefore, in order to achieve teaching goals within a limited teaching time, when teachers conduct international business law courses, they must combine the characteristics of the students' professional selection of teaching content and highlight the key points.

\subsection{Introducing Case Teaching Method into International Commercial Law Teaching}

Case teaching means that teachers use selected case materials according to teaching objectives and teaching tasks, so that students can enter certain specific events and situations, and organize students to organize proactive and inquisitive activities on the composition of events so as to improve A teaching model in which students creatively use the ability to analyze, analyze, and solve practical problems.

The formal application of the case teaching method was Harvard Medical School and Law School in the United States at the beginning of this century. This method has played a very good role in cultivating students' presentations, analysis, and ability to comprehensively compare facts. It embodies a new kind of educational thought and has irreplaceable practical value. Practice has proved that using the case teaching method can receive good teaching results.

"International Business Law" is a comparatively abstract theoretical course. It has many monotonous legal articles and basic concepts. It is highly professional, complicated in content, and has boring features. If you simply teach knowledge, it is difficult to raise students' knowledge. Interest is not conducive to students' understanding and mastery of knowledge, and it is impossible to cultivate students' ability to solve problems. Therefore, stimulating students' interest in learning has become an important issue in classroom teaching. The case-based approach can concretize abstract theories and bring vivid, realistic examples of real life into the classroom, creating an immersive atmosphere.

\subsection{International Commercial Law Teaching Method Reform}

Teaching method is the most traditional teaching method and has played an important role in the teaching of various disciplines. However, with the promotion of student-centered teaching concepts, direct teaching of Fay has been criticized for being led by teachers. However, using the direct method of teaching the right subjects at the right time can have a multiplier effect. For example, for the beginners of international business law, many of the conceptual content and basic international commercial law norms directly teach the teaching effect of the law is very good. For example, the introduction of international commercial law's development history, origins, and the main characteristics of the two legal systems can be achieved through direct instruction. This will enable students to understand the development of international commercial law as soon as possible and establish the basic concept of international commercial law. Form the thinking of international commercial law and integrate it into the curriculum as soon as possible.

The problem-driven approach is a teaching method that focuses on problem-centered teaching activities. Learning with problems can mobilize and inspire students' interest in learning and improve teaching effectiveness. In the teaching process, guide students to think about their solutions by asking questions.

In order to further develop students' self-learning ability, implement a student-centered teaching philosophy and increase students' participation in the course, teachers can arrange the whole class of 
students to be divided into groups to discuss some controversial issues, express their views, and cooperate within the group. The competition among teams mobilizes students' enthusiasm and cultivates students' sense of cooperation and competition. The group discussion can arrange the way of class discussion and class reporting. This method can mobilize the students to collect and discuss related content data and form a consistent presentation. This kind of teaching method is more suitable for learning content that is relatively easy to understand and has a certain connection with reality. Because students do not have a legal knowledge basis, legal issues that are too difficult to understand allow students to collect information on their own.

\section{Conclusion}

The study of law courses is to solve dispute cases. Therefore, the case analysis method is a more commonly used teaching method in the teaching of law. The case analysis method can visualize the abstract theory, facilitate the students to understand and grasp the legal principles, and cultivate the students' thinking ability and practical ability through the analysis of the case questions. This paper believes that in the teaching of international commercial law, it is necessary to categorize the content of teaching and use a variety of the teaching methods for different teaching contents in order to achieve the desired teaching goals.

\section{References}

[1] $\mathrm{Ng}$, E., 2017. Feeding the Minotaur: Is International Commercial Arbitration Hindering the Development of Commercial Law? Asian Dispute Review, 19(1), pp.22-28.

[2] Maniruzzaman, A.F.M., 2017. International development law as applicable law to economic development agreements: a prognostic view. In Globalization and International Investment (pp. 71-126). Routledge.

[3] Oppenheim, L., 2017. The Science of International Law: its task and method. In The Nature of International Law (pp. 93-356). Routledge.

[4] Lindegaard, M.R. and Copes, H., 2017. Observational methods of offender decision making. In The Oxford Handbook of Offender Decision Making. 